\title{
Occupational stress in nursing professionals of a university hospital
}

\author{
Estresse ocupacional em profissionais de enfermagem de um hospital universitário \\ Estrés laboral en profesionales de enfermería de un hospital universitario
}

\section{Lucas Carvalho Santana' ORCID: 0000-0002-7319-8527}

Lúcia Aparecida Ferreira' ORCID: 0000-0001-6469-5444

Lenniara Pereira Mendes Santana' ORCID: 0000-0003-1576-2342

'Universidade Federal do Triângulo Mineiro. Uberaba, Minas Gerais, Brazil.

How to cite this article: Santana LC, Ferreira LA, Santana LPM. Occupational stress in nursing professionals of a university hospital. Rev Bras Enferm. 2020;73(2):e20180997. doi: http://dx.doi.org/10.1590/0034-7167-2018-0997

\section{Corresponding Author:}

Lucas Carvalho Santana

E-mail: lucas_enfer@hotmail.com

EDITOR IN CHIEF: Antonio José de Almeida Filho ASSOCIATE EDITOR: Mitzy Danski

Submission: 02-12-2019

Approval: 06-15-2019

\section{ABSTRACT}

Objectives: To identify the presence of occupational stress in nursing professionals of a university hospital in the inlands of the state of Minas Gerais and examine influence of sociodemographic and occupational characteristics in this disease. Methods: Cross-sectional, exploratory and quantitative study with 124 professional nurses from a university hospital in the inlands of the state of Minas Gerais. The adapted and validated Portuguese version of the Job Stress Scale (JSS) was used for the performance of the study. Results: Most professionals were women $(87.9 \%)$ with a mean age of 40.2 years, $80.6 \%$ were nursing technicians and $71.8 \%$ of the sample had some degree of exposure to occupational stress. Conclusions: The occupational stress index was higher than that observed in previous studies. Data obtained in the study point to the need to implement institutional measures for the prevention of occupational stress, especially by strengthening social support at work.

Descriptors: Nursing Team; Occupational Stress; University Hospital; Nursing Professionals; Occupational Health.

\section{RESUMO}

Objetivos: Identificar a presença de estresse ocupacional nos profissionais de enfermagem de um hospital universitário do interior de Minas Gerais e analisar a influência das características sociodemográficas e ocupacionais neste agravo. Métodos: Estudo transversal, exploratório e quantitativo, realizado com 124 profissionais de enfermagem de um hospital universitário do interior de Minas Gerais. Para sua efetivação, foi utilizada a versão adaptada e validada para o português da escala Job Stress Scale (JSS). Resultados: A maioria dos profissionais era mulheres ( $87,9 \%$ ), com média de idade de 40,2 anos, $80,6 \%$ eram técnicos de enfermagem e $71,8 \%$ da amostra apresentava algum grau de exposição ao estresse ocupacional. Conclusões: $\mathrm{O}$ índice de estresse ocupacional foi superior ao observado em estudos anteriores. Os dados obtidos no estudo apontam para a necessidade de implementar medidas institucionais de prevenção ao estresse ocupacional, sobretudo fortalecendo o apoio social no trabalho.

Descritores: Equipe de Enfermagem; Estresse Ocupacional; Hospital Universitário; Profissionais de Enfermagem; Saúde do Trabalhador.

\section{RESUMEN}

Objetivos: Identificar la presencia de estrés laboral en los profesionales de enfermería de un hospital universitario en el interior de Minas Gerais y analizar la influencia de las características sociodemográficas y ocupacionales en esta enfermedad. Métodos: Estudio transversal, exploratorio y cuantitativo con 124 profesionales de enfermería de un hospital universitario en el interior de Minas Gerais. Para su efectividad, se utilizó la versión portuguesa adaptada y validada de la escala Job Content Questionnaire (JCQ). Resultados: La mayoría de los profesionales eran mujeres (87,9\%), con una edad media de 40,2 años, el $80,6 \%$ eran técnicos de enfermería y el $71,8 \%$ de la muestra tenía algún grado de exposición al estrés laboral. Conclusiones: El índice de estrés laboral fue mayor que el observado en estudios anteriores. Los datos obtenidos en el estudio apuntan a la necesidad de implementar medidas institucionales para prevenir el estrés laboral, especialmente el fortalecimiento del apoyo social en el trabajo.

Descriptores: Grupo de Enfermería; Estrés Laboral; Hospital Universitario; Profesionales de Enfermería; Salud Laboral. 


\section{INTRODUCTION}

Stress has become a very common health problem in the current society, and its occurrence can be attributed to changes in people's lifestyle that have made them debilitated and vulnerable to numerous diseases ${ }^{(1)}$.

The term stress has been used frequently in everyday life and associated with feelings of worry and discomfort. An increasing number of people define themselves as stressed or refer to other individuals in the same situation. This is mostly seen as a negative factor that impairs human beings' performance(2).

By considering stress as a process and not a single reaction, it is not just the type of stressor that determines if stress will develop or not. Cognitive activities used by individuals in interpreting environmental events are fundamental in the stress process ${ }^{(3)}$.

Individuals respond differently to stimulus, which causes internal and external reactions to maintain balance and prevent the establishment of diseases in the body.

Exposure to stress in the workplace should be considered and investigated. Changes in workers' lifestyle over the last decades have generated discussions about occupational stress, which is related to wear and tear resulting from the work environment and work activity. Situations in which individuals live agitated with little time for reflection have become more common, which results in more responses to stress ${ }^{(4)}$.

As different occupations present different stressors, special attention should be given to occupational stressors in the health area, such as relationship problems, conflict of functions, double working hours, pressures exerted by superiors as perceived by each individual and changes within the context of the activity ${ }^{(2,5-6)}$.

Although occupational stress is a common phenomenon to all occupations, it is more easily identified in some specific groups, where sources of pressure in the workplace are higher compared to other professions ${ }^{(7-8)}$.

The nursing profession stands out among those vulnerable to the development of occupational stress. These professionals are directly responsible for the care provided to patients, organization of the hospital department and for various administrative and bureaucratic activities ${ }^{(9)}$. Nursing is one of the most exposed professions to the risk of tension and illness within the hospital institution, because professionals face inadequate working conditions in an unhealthy environment with work overload and repetition of tasks ${ }^{(10)}$.

Occupational stress impacts the daily routine of nursing professionals because it causes physical, psychic, social and cultural damage, and can produce countless consequences for individuals, their family, the company where they work and the community where they live.

\section{OBJECTIVES}

To identify the presence of occupational stress in professionals of the nursing team of a university hospital in the inlands of the state of Minas Gerais and analyze the influence of sociodemographic and occupational characteristics in this disorder.

\section{METHODS}

\section{Ethical aspects}

The study followed the norms established by the current legislation for research with human beings and was approved by the Research Ethics Committee of the Universidade Federal do Triângulo Mineiro (REC/UFTM). The study participants were previously informed by the researcher about the study objectives, that they could withdraw from participating at any time and signed the Informed Consent (IC) form. The risks and losses caused by participation in the study were minimal. However, as questions were related to the work environment, professionals took the questionnaires to be answered at home in order to minimize possible discomforts.

\section{Design, place of study and period}

This study was extracted from the master's dissertation titled "Assessment of occupational stress in the nursing team in a teaching hospital". This cross-sectional, exploratory and quantitative study was conducted in a university hospital in the inlands of the state of Minas Gerais between July and September 2018. The methodological steps of the study were guided by the STROBE tool.

\section{Sample, inclusion and exclusion criteria}

The sample included members of the nursing team (nurses, nursing technicians and nursing assistants) from various departments of a university hospital in Minas Gerais. Professionals working in the hospital who accepted to participate in the study signed the IC and were not absent during the data collection period fulfilled the inclusion criteria.

The calculation of the sample size considered a prevalence of occupational stress exposure of $56.5 \%$, according to a study conducted in a university hospital in the southeastern region of Brazil $^{(11)}$. When considering the prevalence of $56.5 \%$, an accuracy of $8 \%$ and a confidence interval of $95 \%$ for a finite population of 746 professionals, was obtained a sample of 124 professionals.

\section{Study protocol}

The dependent variable evaluated in this study was the exposure to occupational stress. The independent variables were the sociodemographic and occupational characteristics of the sample (sex, age, marital status, children, educational level, position held, time since graduation, work department, work shift, weekly work hours, working time in the institution, employment relationship, salary and presence of another employment engagement).

Two questionnaires were used as data collection instruments; one for sociodemographic and professional characterization of the sample, and the other to evaluate workers' exposure to occupational stress.

The adapted and validated Portuguese version of the Job Stress Scale (JSS) was used to assess the exposure to occupational stress. This scale was originally developed in Sweden (Job Content Questionnaire), and after the cultural adaptation to Portuguese and validation, it was denominated Job Stress Scale, short version. 
This questionnaire was used because it is an internationally recognized scale for the assessment of occupational stress based on the Demand-Control theoretical model, plus it was adapted and validated for Portuguese ${ }^{(12)}$.

The JSS is a Likert scale of 17 items distributed in the three following dimensions: five items evaluate demand, six evaluate control and six evaluate the social support dimension. For each scale dimension, the higher the score, the greater the demand, control or social support perceived ${ }^{(12)}$.

Exposure to occupational stress was assessed by combining high and low levels of the demand and control dimensions by taking into account the Demand-Control model ${ }^{(13)}$.

In order to identify the groups of high and low demand and those of high and low control, was followed the recommendation from researchers who validated the JSS: to adopt the medians of the referred dimensions as a cutoff point by forming two categories for the demand dimension and two for the control dimension.

The professional in situation of high demand (high demand and low control) presents adverse reactions of greater psychological wear and tear. Active work (high psychological demand and high control) allows professionals to have a wide possibility of decision on how and when to develop their tasks, and how to use their intellectual potential for this purpose. Passive work (low psychological demand and low control) produces a gradual atrophy of skill learning. The situation of low demand (combines low demand and high control) is a highly comfortable and ideal working condition ${ }^{(14)}$.

For the stratification of exposure to occupational stress, nursing professionals were classified according to their allocation in groups described in a previous study ${ }^{(15)}$. It suggests that workers in high demand situations are the group with the greatest exposure to occupational stress; those in active work or passive work situations are considered as the intermediate exposure group; and those in situations of low demand are classified as not exposed to stress at work.

According to the authors of the scale, in cases of exposure to stress, the social support dimension works as a modifier of the stress effect at work ${ }^{(13)}$.

\section{Analysis of results and statistics}

Data were processed in IBM ${ }^{\circ}$ SPSS $^{\circ}$ software, version 21 . Descriptive statistics were calculated using mean and median and measures of variability (amplitudes). The bivariate analysis was used through measures of association with contingency tables (relative risk, odds ratio and respective confidence intervals), and application of the Pearson's chi-square test to independent groups for demographic and occupational dichotomous predictors. To identify the association between the JSS dimensions, sociodemographic and occupational variables, and occupational stress exposure, was used the binomial logistic regression analysis by adjusting for other potentially relevant variables.

\section{RESULTS}

The sample consisted of 109 (87.9\%) female professionals with a mean age of 40.2 years (minimum of 22 and maximum of 68 years), of whom 66 (53.2\%) were married or in a common-law marriage, and 90 (72.6\%) had children.
The professional characteristics of the studied sample are shown in Table 1.

Table 1 - Professional characterization of the sample $(\mathrm{N}=124)$, Uberaba, Minas Gerais, Brazil, 2018

\begin{tabular}{|c|c|c|c|}
\hline & & $\mathbf{n}$ & $\%$ \\
\hline \multirow[t]{3}{*}{ Position } & Nursing assistants & 15 & 12.1 \\
\hline & Nursing technicians & 85 & 68.5 \\
\hline & Nurses & 24 & 19.4 \\
\hline \multirow[t]{3}{*}{ Educational level } & High school & 46 & 37.1 \\
\hline & Superior education & 38 & 30.6 \\
\hline & Postgraduation & 40 & 32.3 \\
\hline \multirow[t]{5}{*}{ Time since graduation } & Up to 5 years & 6 & 5.0 \\
\hline & 6 to 10 years & 39 & 32.5 \\
\hline & 11 to 15 years & 28 & 23.3 \\
\hline & 16 to 20 years & 25 & 20.8 \\
\hline & More than 21 years & 22 & 18.3 \\
\hline \multirow[t]{2}{*}{ Weekly workload* } & 36 hours & 89 & 72.4 \\
\hline & 40 hours & 34 & 27.6 \\
\hline \multirow[t]{3}{*}{ Work shift } & Morning & 25 & 20.1 \\
\hline & Evening & 38 & 30.6 \\
\hline & Night & 61 & 49.2 \\
\hline \multirow[t]{5}{*}{ Working time at the institution } & Up to 5 years & 63 & 51.2 \\
\hline & 6 to 10 years & 16 & 13.0 \\
\hline & 11 to 15 years & 16 & 13.0 \\
\hline & 16 to 20 years & 13 & 10.6 \\
\hline & More than 21 years & 15 & 12.2 \\
\hline \multirow[t]{4}{*}{ Salary** } & Up to 2 minimum wages & 10 & 8.2 \\
\hline & 2 to 5 minimum wages & 79 & 64.7 \\
\hline & 5 to 10 minimum wages & 31 & 25.4 \\
\hline & $\begin{array}{l}\text { More than } 10 \text { minimum } \\
\text { wages }\end{array}$ & 2 & 1.6 \\
\hline \multirow{2}{*}{$\begin{array}{l}\text { Presence of another } \\
\text { employment engagement }\end{array}$} & Yes & 15 & 12.2 \\
\hline & No & 108 & 87.8 \\
\hline
\end{tabular}

Note: *There is no regulation of the state's regional nurse board on the maximum weekly workload; ** Minimum wage in force during the data collection period.

The sample was analyzed considering the three dimensions proposed by the scale used: demand, control and social support. For the bivariate statistical analysis, the median of the total score of each dimension was used as a cutoff point for its dichotomization. Values below the median were allocated to groups of low demand, control or social support. Values equal to or above the median were allocated to groups of high demand, control, or social support.

According to the dichotomization of dimensions of the JSS, professionals were allocated in four quadrants as recommended by the model. Thus, was observed the following distribution: $30.6 \%$ in the high demand situation; $28.2 \%$ in the low demand; $21.8 \%$ in active work; and $19.4 \%$ in passive work.

Table 2 shows that, although without statistical significance, the prevalence of stress exposure in the sample studied was higher among surgical professionals (88.9\%), followed by wards $(79.1 \%)$, emergency department $(72.2 \%)$, center of sterilized material (62.5\%) and the ICU - Intensive Care Unit (55.6\%).

The influence of sociodemographic and professional variables on stress exposure is described in table 3. According to data analyzed, presenting low social support and not working in ICU 
were considered statistically significant stress exposure factors $(p=0.01)$. In addition, stress was more present in men, unmarried people, those with children, professionals in higher education positions, under statutory labor regime, individuals with another employment engagement, of the night shift and with a weekly workload greater than 36 hours, but these variables did not have statistical significance.

Table 2 - Exposure to stress according to the work department ( $n=123)$, Uberaba, Minas Gerais, Brazil, 2018

\begin{tabular}{|c|c|c|c|c|c|}
\hline & \multicolumn{4}{|c|}{ Exposure to stress } & \multirow{3}{*}{$\underset{\text { value }}{p}$} \\
\hline & \multicolumn{2}{|c|}{ Yes } & \multicolumn{2}{|c|}{ No } & \\
\hline & $\mathbf{n}$ & $\%$ & $\mathbf{n}$ & $\%$ & \\
\hline \multicolumn{6}{|l|}{ Work department } \\
\hline Wards & 34 & 79.1 & 9 & 20.9 & \multirow{5}{*}{0.07} \\
\hline ICU & 20 & 55.6 & 16 & 44.4 & \\
\hline Surgical area & 16 & 88.9 & 2 & 11.1 & \\
\hline Emergency Department & 13 & 72.2 & 5 & 27.8 & \\
\hline Center of Sterilized Material & 5 & 62.5 & 3 & 37.5 & \\
\hline
\end{tabular}

Although not statistically significant, the professional with another employment engagement had 2.24 more chances of exposure to occupational stress compared to professionals with only one job. Professionals on night shifts had 1.56 more chances of exposure to occupational stress compared to professional working on day shifts.

Table 4 presents the final binomial logistic regression model for variables associated with occupational stress exposure. The selection of variables described in this process was based on those used in specific literature on this theme ${ }^{(8,16-19)}$.

In the final logistic regression model, the factors associated with exposure to occupational stress in nursing professionals were the work department $(p=0.01)$ and social support $(p=0.01)$.
Table 4 - Final binomial logistic regression model for variables of occupational stress exposure ( $n=119)$, Uberaba, Minas Gerais, Brazil, 2018

\begin{tabular}{|c|c|c|c|}
\hline & Variables & $\mathrm{OR}^{*}(\mathrm{Cl})$ & $p$ value ${ }^{*}$ \\
\hline Sex & $\begin{array}{l}\text { Male } \\
\text { Female }\end{array}$ & $1.50(0.40-5.66)$ & 0.55 \\
\hline $\begin{array}{l}\text { Educational level of } \\
\text { the position }\end{array}$ & $\begin{array}{l}\text { Superior education } \\
\text { High school }\end{array}$ & $1.89(0.55-6.47)$ & 0.31 \\
\hline Other engagement & $\begin{array}{l}\text { Yes } \\
\text { No }\end{array}$ & $2.24(0.49-10.31)$ & 0.30 \\
\hline Work shift & $\begin{array}{l}\text { Night } \\
\text { Day }\end{array}$ & $1.56(0.63-3.87)$ & 0.34 \\
\hline Work department & $\begin{array}{l}\text { Other departments } \\
\text { ICU }\end{array}$ & $3.91(1.49-10.25)$ & 0.01 \\
\hline Social support & $\begin{array}{l}\text { Low } \\
\text { High }\end{array}$ & $3.60(1.34-9.68)$ & 0.01 \\
\hline
\end{tabular}

\section{DISCUSSION}

In the present study, the sample was represented mainly by women (87.9\%), which is corroborated by several studies demonstrating that the Brazilian nursing team is structurally and historically female $\mathrm{e}^{(15,19-21)}$.

Regarding age, $60.7 \%$ of professionals were younger than 40 years old, which characterizes the presence of a young workforce in the nursing team of the institution. Such data are reinforced by the Brazilian Nursing Profile survey, in which was identified that $61.7 \%$ of nursing professionals were in the age group of up to 40 years $^{(21)}$.

The nursing team represented in the study consisted of $80.6 \%$ of nursing assistants and technicians, and $19.4 \%$ of nurses, which is in line with data obtained in other studies ${ }^{(19-21)}$.

Table 3 - Influence of sociodemographic and occupational variables on stress exposure (N=124), Uberaba, Minas Gerais, Brazil, 2018

\begin{tabular}{|c|c|c|c|c|c|c|c|c|}
\hline & & \multicolumn{4}{|c|}{ Exposure to stress } & \multirow{3}{*}{ PR (CI) } & \multirow{3}{*}{ OR (CI) } & \multirow{3}{*}{$p$ value } \\
\hline & & \multicolumn{2}{|c|}{ Yes } & \multicolumn{2}{|c|}{ No } & & & \\
\hline & & $\mathbf{n}$ & $\%$ & $\mathbf{n}$ & $\%$ & & & \\
\hline Sex & $\begin{array}{l}\text { Male } \\
\text { Female }\end{array}$ & $\begin{array}{l}11 \\
78\end{array}$ & $\begin{array}{l}73.3 \\
71.6\end{array}$ & $\begin{array}{c}4 \\
31\end{array}$ & $\begin{array}{l}26.7 \\
28.4\end{array}$ & $1.02(0.74-1.42)$ & $1.09(0.32-3.69)$ & 0.89 \\
\hline Partner & $\begin{array}{l}\text { No } \\
\text { Yes }\end{array}$ & $\begin{array}{l}42 \\
47\end{array}$ & $\begin{array}{l}72.4 \\
71.2\end{array}$ & $\begin{array}{l}16 \\
19\end{array}$ & $\begin{array}{l}27.6 \\
28.8\end{array}$ & $1.02(0.81-1.27)$ & $1.06(0.48-2.32)$ & 0.88 \\
\hline Children & $\begin{array}{l}\text { Yes } \\
\text { No }\end{array}$ & $\begin{array}{l}66 \\
22\end{array}$ & $\begin{array}{l}73.3 \\
66.7\end{array}$ & $\begin{array}{l}24 \\
11\end{array}$ & $\begin{array}{l}26.7 \\
33.3\end{array}$ & $1.10(0.84-1.44)$ & $1.37(0.58-3.25)$ & 0.47 \\
\hline Schooling of the position & $\begin{array}{l}\text { Superior education } \\
\text { High school }\end{array}$ & $\begin{array}{l}20 \\
69\end{array}$ & $\begin{array}{l}83.3 \\
69.0\end{array}$ & $\begin{array}{c}4 \\
31\end{array}$ & $\begin{array}{l}16.7 \\
31.0\end{array}$ & $1.21(0.97-1.51)$ & $2.25(0.71-7.12)$ & 0.16 \\
\hline Work regime & $\begin{array}{l}\text { Public servant } \\
\text { Formal contract }\end{array}$ & $\begin{array}{l}29 \\
60\end{array}$ & $\begin{array}{l}80.6 \\
68.2\end{array}$ & $\begin{array}{c}7 \\
28\end{array}$ & $\begin{array}{l}19.4 \\
31.8\end{array}$ & $1.18(0.95-1.46)$ & $1.93(0.76-4.95)$ & 0.16 \\
\hline Other engagement & $\begin{array}{l}\text { Yes } \\
\text { No }\end{array}$ & $\begin{array}{l}12 \\
76\end{array}$ & $\begin{array}{l}80.0 \\
70.4\end{array}$ & $\begin{array}{c}3 \\
32\end{array}$ & $\begin{array}{l}20.0 \\
29.6\end{array}$ & $1.14(0.86-1.51)$ & $1.68(0.45-6.37)$ & 0.44 \\
\hline Work shift & $\begin{array}{l}\text { Night } \\
\text { Day }\end{array}$ & $\begin{array}{l}45 \\
44\end{array}$ & $\begin{array}{l}73.8 \\
69.8\end{array}$ & $\begin{array}{l}16 \\
19\end{array}$ & $\begin{array}{l}26.2 \\
30.2\end{array}$ & $1.06(0.85-1.32)$ & $1.21(0.55-2.66)$ & 0.63 \\
\hline Weekly workload & $\begin{array}{l}\text { More than } 36 \text { hours } \\
\text { Up to } 36 \text { hours }\end{array}$ & $\begin{array}{l}26 \\
62\end{array}$ & $\begin{array}{l}76.5 \\
69.7\end{array}$ & $\begin{array}{c}8 \\
27\end{array}$ & $\begin{array}{l}23.5 \\
30.3\end{array}$ & $1.10(0.87-1.38)$ & $1.41(0.57-3.52)$ & 0.45 \\
\hline Work department & $\begin{array}{l}\text { Other departments } \\
\text { ICU }\end{array}$ & $\begin{array}{l}68 \\
20\end{array}$ & $\begin{array}{l}78.2 \\
55.6\end{array}$ & $\begin{array}{l}19 \\
16\end{array}$ & $\begin{array}{l}21.8 \\
44.4\end{array}$ & $1.41(1.03-1.92)$ & $2.86(1.25-6.57)$ & 0.01 \\
\hline Social support & $\begin{array}{l}\text { Low } \\
\text { High }\end{array}$ & $\begin{array}{l}40 \\
46\end{array}$ & $\begin{array}{l}85.1 \\
62.2\end{array}$ & $\begin{array}{c}7 \\
28\end{array}$ & $\begin{array}{l}14.9 \\
37.8\end{array}$ & $1.37(1.10-1.70)$ & $3.48(1.37-8.82)$ & 0.01 \\
\hline
\end{tabular}

Note: PR: Prevalence Ratio; OR: Odds Ratio; Cl: $95 \%$ confidence interval; $p$ : Significance level ( $p<0.05)$. 
The proportion of nurses/nursing assistants and technicians can be explained by the fact that nurses are responsible for the coordination of the nursing team, and as a priority, for the care of serious patients ${ }^{(19)}$.

In a national study conducted to characterize the training of the nursing team, $80.0 \%$ of Brazilian nurses did some postgraduate course and $34.3 \%$ of nursing assistants and technicians had an undergraduate degree ${ }^{(22)}$. In the present study, were found higher rates, and $95.8 \%$ of nurses and $68.0 \%$ of mid-level professionals had an educational level above that required for the position.

In this study, $71.8 \%$ of nursing professionals at the institution had some degree of exposure to stress and $30.6 \%$ of professionals were in a situation of high demand at work. This value is above that observed in similar studies ${ }^{(15,17,23)}$.

In a study conducted in a university hospital in the city of Rio de Janeiro, $56.5 \%$ of the nursing staff presented some level of stress ${ }^{(11)}$. In another study developed in a university hospital in the south of Brazil, 27.4\% of the professionals presented occupational stress ${ }^{(23)}$. In a study conducted in the northeast region of Brazil, was found a $22.0 \%$ rate of exposure to stress among nursing professionals ${ }^{(19)}$.

The final logistic regression model showed that the work department and the social support influence the exposure to occupational stress, because were found statistically significant association results $(p=0.01)$. Professionals working in the ICU of the institution had 3.91 fewer chances of exposure to occupational stress compared to professionals working in other departments of the hospital.

This finding differs from the literature, which advocates greater exposure to occupational stress in intensive care units ${ }^{(11,24)}$.

Previous studies investigating occupational stress factors in ICU workers suggest that the physical and emotional exhaustion caused by work activities, reduced human resources, and lack of emotional support can trigger this condition. They also report that recognition at work, cooperation among team members, professional respect and psychological support can be protective elements against illness ${ }^{(25)}$.

In the present study, $60 \%$ of professionals working in the ICU reported perceiving high social support and $55.6 \%$ reported having high control over the work performed. According to the theoretical model used in the study, these factors can be considered as protectors against stress exposure.

In a study conducted in the south of Brazil, the inadequate physical structure and lack of material resources were identified as stressors, mainly in closed departments, such as surgical areas and ICUs. Another aspect mentioned as a stressor was the managerial role of nurses who, in addition to the technical activities inherent to the profession, have bureaucratic functions, such as responsibility for the technical team, functional organization of the unit, planning of work schedules, vacations and worksheets for organization of the sector ${ }^{(26)}$.

In relation to the high occupational stress rate identified in professionals from other departments of the hospital, in the institution in question, the size of staff is below the expected and a high rate of absenteeism has been observed in the nursing team, which favors work overload and stress exposure.

According to the final logistic regression model, professionals who receive lower support from bosses and co-workers have 3.60 more chances of exposure to stress than those with high social support.
Such data is corroborated by findings from a study conducted in public hospitals in southern Brazil, in which was observed that the higher the perception of social support received, the less reports of exhausting work $^{(9)}$.

Still regarding social support, are described several mechanisms through which social support in the work environment can affect workers' health and the development of stress. Social support acts as a moderator of tension and may diminish its potency or increase coping strategies ${ }^{(16)}$.

Thus, the presence of social support in the workplace reduces the negative loads of occupational stress and can contribute to workers establishing effective resilience mechanisms in the face of common difficulties in the work routine.

The fact that night shift professionals with two employment engagements are more likely to be exposed to occupational stress can be supported by a study conducted in Ohio-US. In this study, it was shown that shift work and long working hours increase the risk of reduced performance at work, obesity, stress, injuries and a wide range of diseases related to poor health behaviors ${ }^{(27)}$.

\section{Limitations of the study}

Some limitations should be considered in the generalization of results of this study. The high prevalence of occupational stress in the studied sample and the low population adherence to participation in the study made the statistical analysis more difficult, which may have complicated the associations of cause and effect of the studied phenomenon.

\section{Contributions to the health area}

Conducting studies on occupational stress in nursing professionals is paramount for maintaining and promoting workers' health. This is a current and relevant issue, since nursing professionals are continually exposed to situations of pressure, work overload and precarious working conditions. Furthermore, was identified a lack of scientific knowledge about this theme among nursing professionals in university hospitals.

The development of future studies is suggested for identifying the possible reasons for ICU professionals of the institution presenting lower levels of stress exposure when compared to other departments.

Deepening the studies related to this subject is also important given the nature of services provided by nursing professionals, because the quality and effectiveness of their work can have a decisive impact on patients' health.

\section{CONCLUSIONS}

Occupational stress in nursing professionals should be considered a predisposing factor to several health problems, which increases the rates of professional dissatisfaction and absenteeism in institutions.

Data obtained in this study showed the need to implement institutional measures for occupational stress prevention, particularly for strengthening social support at work.

Given the context, this study may support institutional programs for occupational stress prevention and promotion of satisfaction, wellbeing and quality of life at work. 


\section{REFERENCES}

1. Tanure B, Carvalho Neto A, Santos CMM, Patrus R. Estresse, doença do tempo: um estudo sobre o uso do tempo pelos executivos brasileiros. Estud Pesqui Psicol [Internet]. 2014 [cited 2017 Dec 07];14(1):65-88. Available from: http://pepsic.bvsalud.org/scielo.php?script=sci_arttext\& pid $=$ S1808-42812014000100005

2. Monte PF, Lima FET, Neves FMO, Studart RMB, Dantas RT. Stress among professional nurses working in intensive care units. Acta Paul Enferm. 2013;26(5):421-7. doi: 10.1590/S0103-21002013000500004

3. Lazarus RS, Folkman S. Stress, apraisal and coping. Nova lorque: Springer; 1984.

4. Calais SL. Diferenças entre homens e mulheres na vulnerabilidade ao stress. In: LIPP MEN (Org.). Mecanismos neuropsicofisiológicos do stress: teoria e aplicações clínicas. 3a ed. São Paulo: Casa do Psicólogo; 2010. p. 87-90.

5. Dalri RCMB, Silva LA, Mendes AMOC, Robazzi MLCC. Nurses' workload and its relation with physiological stress reactions. Rev Latino-Am Enfermagem. 2014;22(6):959-65. doi: 10.1590/0104-1169.3292.2503

6. Maffia LN, Pereira LZ. Estresse no trabalho: estudo com gestores públicos no estado de Minas Gerais. Rev Eletr Adm. 2014;79(3):658-80. doi: 10.1590/1413-2311.0052014.47163

7. Ferreira JS, Ribeiro KV, Caramaru PS, Hanzelmann RS, Velasco AR, Passos JP. Stress and coping strategies in workers of nursing of a family health unit. J Res Fundam Care Online. 2017;9(3):818-23. doi: 10.9789/2175-5361.2017.v9i3.818-823

8. Andolhe R, Barbosa RL, Oliveira EM, Costa ALS, Padilha KG. Stress, coping and burnout among Intensive Care Unit nursing staff: associated factors. Rev Esc Enferm USP. 2015;49 (n. esp.):58-64. doi: 10.1590/S0080-623420150000700009

9. Scholze AR, Martins JT, Robazzi MLCC, Haddad MCFL, Galdino MJQ, Ribeiro RP. Occupational stress and associated factors among nurses at public hospitals. Cogitare Enferm. 2017;22(3):e50238. doi: 10.5380/ce.v22i3.50238

10. Cacciari P, Hadadd MCL, Vannuchi MTO, Dalmas JC. Estado de saúde de trabalhadores de enfermagem em readequação e readaptação funcional. Rev Bras Enferm. 2013;66(6):860-5. doi: 10.1590/S0034-71672013000600008

11. Kestenberg CCF, Felipe ICV, Rossone FO, Delphim LM, Teotonio MC. O estresse do trabalhador de enfermagem: estudo em diferentes unidades de um hospital universitário. Rev Enferm UERJ. 2015;23(1):45-51. doi: 10.12957/reuerj.2015.11487

12. Alves MGM, Chor D, Faerstein E, Lopes CS, Werneck GL. Short version of the "job stress scale": a Portuguese-language adaptation. Rev Saúde Pública. 2004;38(2):164-71. doi: 10.1590/S0034-89102004000200003

13. Karasek RA. Job demands, job decision latitude, and mental strain: implications for job redesigning. Adm Sci Q. 1979;24(3):285-308. doi: $10.2307 / 2392498$

14. Araújo TM, Aquino E, Menezes G, Santos CO, Aguiar L. Aspectos psicossociais do trabalho e distúrbios psíquicos entre trabalhadoras de enfermagem. Rev Saúde Pública. 2003;37(4):424-33. doi: 10.1590/\$0034-89102003000400006

15. Azevedo BDS, Nery AA, Cardoso JP. Occupational stress and dissatisfaction with quality of work life in nursing. Texto Contexto Enferm. 2017;26(1):1-11. doi: 10.1590/0104-07072017003940015

16. Silva JLL, Teixeira LR, Soares RS, Costa FS, Aranha JS, Teixeira ER. Estrés y factores psicosociales en el trabajo de enfermeros intensivistas. Enferm Glob. 2017;48:80-93. doi: 10.6018/eglobal.16.4.249321

17. Azizah A, Rozainee K, Nada I, Izreen S, Norhafizah Z. The prevalence of occupational stress and its association with socio-demographic factors among lecturers in a private university in Malaysia. Int J Public Health Clin Sci [Internet]. 2016 [cited 2018 Oct 16];3(4):63-71. Available from: http://publichealthmy.org/ejournal/ojs2/index.php/ijphcs/article/view/326/270

18. Silva AM, Guimarães LAM. Occupational stress and quality of life in nursing. Paidéia (Ribeirão Preto). 2016;26(63):63-70. doi: $10.1590 / 1982-43272663201608$

19. Rodrigues CCFM, Salvador PTCO, Assis YMS, Gomes ATL, Bezerril MS, Santos VEP. Stress among nursing team members. J Nurs UFPE On Line. 2017;11(2):601-8. doi: 10.5205/reuol.10263-91568-1-RV.1102201715

20. Trettene AS, Andrade CS, Von Kostrisch LM, Tabaquim MLM, Razera APR. Estresse em profissionais de enfermagem atuantes em um hospital especializado. J Nurs UFPE On Line. 2016;10(12):4450-8. doi: 10.5205/reuol.9978-88449-6-ED1012201603

21. Machado MH, Aguiar Filho W, Lacerda WF, Oliveira E, Lemos W, Wermelinger M, et al. Características gerais da enfermagem: o perfil sócio demográfico. Enferm Foco. 2016;7(esp):9-14. doi: 10.21675/2357-707X.2016.v7.nESP.686

22. Machado $\mathrm{MH}$, Wermelinger $\mathrm{M}$, Vieira $\mathrm{M}$, Oliveira $\mathrm{E}$, Lemos $\mathrm{W}$, Aguiar Filho W, et al. Aspectos gerais da formação da enfermagem: o perfil da formação dos enfermeiros, técnicos e auxiliares. Enferm Foco. 2016;6(2/4):15-34. doi: 10.21675/2357-707X.2016.v7.nESP.687

23. Ribeiro RP, Marziale MHP, Martins JT, Galdino MJQ, Ribeiro PHV. Occupational stress among health workers of a university hospital. Rev Gaúcha Enferm. 2018;39:e65127. doi: 10.1590/1983-1447.2018.65127

24. Souza ISN, Silva FJ, Gomes RLV, Frazão IS. Situações estressantes de trabalho dos enfermeiros de um hospital escola. Rev Enferm UFSM. 2013;3(2):287-95. doi: 10.5902/217976928322

25. Monteiro JK, Oliveira ALL, Ribeiro CS, Grisa GH, Agostini N. Adoecimento psíquico de trabalhadores de unidades de terapia intensiva. Psicol Ciênc Prof. 2013;33(2):366-79. doi: 10.1590/S1414-98932013000200009 
26. Barboza MCN, Braga LL, Perleberg LT, Bernardes LS, Rocha IC. Estresse ocupacional em enfermeiros atuantes em setores fechados de um hospital de Pelotas/RS. Rev Enferm UFSM. 2013;3(3):374-82. doi: 10.5902/217976927624

27. Caruso CC. Negative impacts of shiftwork and long work hours. Rehabil Nurs. 2014;39(1):16-25. doi: 10.1002/rnj.107 